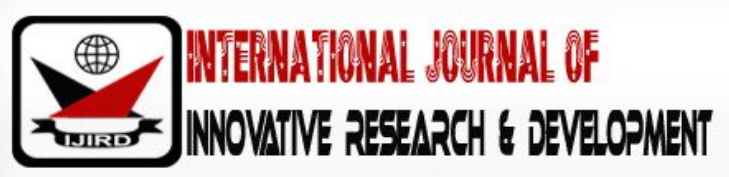

ISSN 2278 - 0211 (Online)

\section{Examination of Technological, Organizational and External Factors of E-Readiness of Banks}

\author{
Carlo K.M.H. Adadevoh \\ Ph. D. Student, Accra Institute of Technology, Open University of Malaysia, Malaysia
}

\begin{abstract}
:
Banks in Ghana have improved their service provision by using a combination of traditional and electronic mediums as a consequent of the liberalization of the banking and telecommunications sectors. However, the e-readiness potential of a country does not guarantee adoption of ICT by organizations within it. The purpose of this study is to establish factors which influence e-readiness adoption as pertains in Ghanaian banks. Factors will be considered under perceived organizational ereadiness and perceived environmental e-readiness of the banks under study.
\end{abstract}

Keywords: E-readiness, E-banking, E-commerce, Perceived E-readiness model

\section{Introduction}

ICT has become the main conduit for global interactions [11, 21]. Staying relevant in an ICT dominated environment compels governments, institutions and individuals to incorporate ICT into its activities. This is because ICT has become an indispensable feature of today's world [19]. The banking industry is one such institution which has been influenced by ICT improvements over the years. However, effective participation in an ICT-based system requires the existence of certain conditions. Assessments of these conditions are known as electronic-readiness (e-readiness) [3].Specifically, this study seeks to identify whether technological, organizational and external factors facilitate the incorporation of electronic commerce within Ghana's banking industry.

\section{E-Readiness}

E-readiness measures the state of an institution to use ICT and the opportunities ICT presents, especially as influenced by infrastructure, human resources and policy factors [3,9]. Specifically, it shows how an institution can create value additions using ICT [15]. These assessments are mostly conducted to identify the differences both between and within specific identified societies or sectors [22].

E-readiness assessments have been conducted increasingly over the years, evidenced in the quantum of both country and institutional assessment reports [15,22].These studies have been necessitated by the observation of different factors which influence electronic transactions [15]. E-readiness covers institutional and individual capacities in the use of ICT as a conduit for transactions, though it initially started with a focus on governments [3].

A benefit of e-readiness is that, it helps determine the status of a body to effectively interact with other actors using an ICT interface. Results from the status determination then inform which policies should be created and implemented to improve participation in transactional processes. E-readiness assessments create employment opportunities within the industries by compelling institutions to incorporate ICT (infrastructure and personnel) into its activities, in addition to opportunities for service providers. Incorporating ICT into institutional activities subsequently result in improvements in the efficiency of the institution by reducing transactional times and processes, though this is not absolute in itself. E-banking ultimately reduces the quantum of physical cash that must be moved around, and the security risks associated with that [3, 5 , $10,19]$.

\section{E-Readiness of Banks in Ghana}

Banks are legal bodies with the mandate to manage funds within a country [12]. In accordance with improved ICT, banks must be innovative in the provision of services to clients. Technological improvements in the areas of computing, and communication has allowed the adoption of electronic-banking [19]. E-banking involves all financial service transactions that 
are conducted using an electronic interface with little to no direct involvement of a worker of the bank [14]. A consequent of this is changes that have been made to banking practices both at the global and local levels [11].

The 1990s has been associated with the emergence of e-commerce [4]. Through e-commerce, banks have increasingly shifted from requiring client presence at banks to conducting commercial transactions using telecommunications networks [6, 8]. Neglecting this new trend would be to the detriment of the non-innovative bank especially when other banks are using modern technology to improve upon the services rendered to their clients [2]. The increased incorporation of ICT by banks can be attributed to two main reasons. The first is the significant reduction in operation costs by banks by using a cheaper service delivery channel $[16,18]$. Second is the benefit to customers in terms of easier access to and control of financial services and accounts [16].

Electronic transactions, despite its widespread practice, are country specific. In the absence of proper contextualization, understanding e-readiness within a country or institution becomes challenging. Comparatively, developed countries fare better on the basis of ICT development and use compared with developing countries, Ghana included [9]. In Ghana, the development of the banking industries and their increased use of ICT have been associated with the liberalization of both the banking industry and telecommunication industries [1]. Ghana's banking sector has grown from one bank in 1874 to 34 by December 2016 [7]. Asa modern practice, internet banking involves the use of an internet system to access and provide banking services using electronic devices [17].

\section{Perceived E-Readiness Model (Perm)}

The likelihood of organizations within a highly ranked e-readiness society using ICT is not automatic [10]. A review of some-readiness reports unearths some common factors associated with the development of e-commerce. These factors include infrastructure/ technology, accessibility, software, e-environment, policy enablers, education and human resources [3, 9].These factors are mostly grouped under Perceived Organizational E-Readiness (POER) and Perceived External E-Readiness (PEER) $[10,13]$.

The purpose of this paper is therefore to help identify which factors actually contribute to the adoption of ICT within the banking industry in Ghana. The study adopts Molla and Lickers' (2005) perceived e-readiness model (PERM) since it covers both internal and external factors [4]. Under this model, POER factors include commitment, governance, awareness, human resource, business resource and technology resource. PEER covers government, market forces and supporting industries [4].

Commitment shows the level of support that an institution has to promote e-readiness. The political structure within the institution and how it promotes ICT adoption falls under governance factors. Awareness entails the recognition of the opportunities and setbacks that ICT presents to an institution. The availability of personnel with the requisite ICT skills in an institution is the domain of human resources. Business resources concern itself with the nature of relationship which exists within the institution upon which improved ICT-based interactions can be modeled on. Technology resource determines the level of technical preparedness to facilitate e-readiness [4].

At the level of government, enablers of ICT adoption are considered. The nature of transactions mostly used within a particular society is considered under the market factors. Finally, the presence of industries to provide and support ICT systems is considered under support industry factors [4]. An inter-play of these various factors will help establish their role in the facilitation of e-readiness.

\section{Methodology}

The study population of the study comprises 34 banks duly acknowledged by Bank of Ghana by December 2016, of which a sample of 18 was selected. Primary data was obtained using a structured questionnaire, while secondary data was sourced from existing literature and reports. The questionnaire covered demographics of the banks, as well as technological, organizational and environmental factors which influence e-readiness adoption in banks as measured on a 5-point Liker scale. Results from the study was analyzed, and findings presented using tables

\section{Results}

\subsection{Data Description}

Table 1 present the reliability scores of the independent variables used in the study. The reliability analysis shows the extent to which the independent variables are reliable and can be used in generalizing the results obtained. Based on the results of all the independent variables passed the reliability test.

Overall, 90 participants from the various banks engaged in this study, only 70 questionnaires were retrieved for the analysis representing $77.8 \%$. Most of the respondents engaged in the study were IT officers and they constituted about $36 \%$. About 21\% were also clerks in their respective banks. Regarding the number of years, the banks have been in operation; about $50 \%$ of the respondents constituting the majority noted that their banks have been in operation for a period ranging between 7 to 10 years. Other banks have also been in operation for above 10 years. Again, most of the respondents indicated that their banks have over 20 branches across the country. Finally, $47.1 \%$ of the respondents had attained Bachelor's degree, $47.1 \%$ had attained Post-Graduate degree and 22.9\% had attained Professional certificate. 


\begin{tabular}{|c|c|c|}
\hline Variables & Items & Reliability \\
\hline Technological factors & 8 & 0.824 \\
\hline Organizational factors & 7 & 0.892 \\
\hline Governmental e-readiness & 4 & 0.766 \\
\hline Supporting Industries & 8 & 0.733 \\
\hline Market forces & 2 & 0.803 \\
\hline Customers e-readiness & 4 & 0.753 \\
\hline
\end{tabular}

Table 1: Reliability Analysis

\begin{tabular}{|c|c|c|}
\hline Variable & Frequency & Percent (\%) \\
\hline Position & & \\
\hline Assistant Vice President & 5 & 7.1 \\
\hline Branch Manager & 10 & 14.3 \\
\hline Operation Manager & 10 & 14.3 \\
\hline OG-1 & 5 & 3.1 \\
\hline IT Officer & 25 & 21.4 \\
\hline Clerk & 15 & 7.1 \\
\hline Years in operations & & 21.4 \\
\hline 1-3 years & 5 & 50.0 \\
\hline 4-6 years & 15 & 21.4 \\
\hline 7-10 years & 35 & 24.3 \\
\hline Above 10 years & 15 & 21.4 \\
\hline Number of branches & & 54.3 \\
\hline 11-15 & 17 & \\
\hline 15-20 & 15 & 30.0 \\
\hline Above 20 & 38 & 47.1 \\
\hline Education & & 22.9 \\
\hline Bachelor's Degree & 21 & \\
\hline Post-Graduate Degree & 33 & \\
\hline Professional certificate & 16 & \\
\hline Table $:$ Dofre & & \\
\hline
\end{tabular}

Table 2: Demographic Characteristics of Respondents

Results of the multiple linear regression analysis are presented in Table 3. As can be observed from Table 3, the adjusted $\mathrm{R}^{2}$ obtained was 0.824 which suggest that $82.4 \%$ of the changes in the e-readiness can be explicated by the changes in the independent variables (Technological, organizational and external factors). The overall model was found to be statistically significant $(F=54.745, p=0.000)$. Table 4 also present the regression estimates of the independents variables. As shown in Table 4, technological factors, government e-readiness, supporting industries and consumer e-readiness had a significant effect on banks e-readiness.

\begin{tabular}{|c|c|c|}
\hline Adjusted R Square & F & Sig. \\
\hline 0.824 & 54.745 & 0.000 \\
\hline
\end{tabular}

Table 3: Multiple Linear Regressions

Predictors: (Constant), Technological, Organizational, Governmental, consumer e-readiness, Supporting, Market forces

\begin{tabular}{|c|c|c|c|c|c|}
\hline \multirow[t]{2}{*}{ Model } & \multicolumn{2}{|c|}{ Unstandardized Coefficients } & Standardized Coefficients & \multirow[t]{2}{*}{$\mathbf{t}$} & \multirow[t]{2}{*}{ Sig. } \\
\hline & $\mathrm{B}$ & Std. Error & Beta & & \\
\hline (Constant) & -1.232 & .463 & & -2.662 & .010 \\
\hline Technological & -.324 & .084 & -.299 & -3.839 & .000 \\
\hline Organizational & .118 & .067 & .117 & 1.756 & .084 \\
\hline Governmental & .897 & .056 & .972 & 16.030 & .000 \\
\hline Supporting & -.151 & .082 & -.110 & -2.851 & .049 \\
\hline Market forces & -.020 & .065 & -.023 & -.315 & .754 \\
\hline $\begin{array}{l}\text { Consumer } \\
\text { readiness }\end{array}$ & .634 & .080 & .502 & 7.908 & .000 \\
\hline
\end{tabular}

Table 4: Regression Estimates

Dependent Variable: E-Readiness 


\subsection{Discussion}

In this study, we examined the influences of the TOE framework (Technological, organizational and supporting factors) on banks e-readiness. The findings from the study showed that among other things, the e-readiness of Ghanaian banks are dependent on the technology readiness, government readiness, supporting industries and consumer readiness. The result implies that technology infrastructure is key to every banks e-readiness. This supports the findings of Turban et al. (2004) that the adoption of ecommerce is dependent on the set of IT-related skills and knowledge.

The result also suggests that government e-readiness government plays a critical role in the readiness of ecommerce among Ghanaian banks.This support Palacios (2003) findings that government plays a key role in the development of ecommerce by providing the telecommunication infrastructure, institutional support and providing official status to electronic transactions and documents. Again, the result obtained indicated that the existence of adequate and a developed support industry influences banks e-readiness. This is consistent with the findings of Molla and Licker (2005) who found that the presence of supporting industries e-readiness within the to influence the adoption of ecommerce in Nigeria.

On the other hand, respondents noted that the current organizational framework and market forces will not be enough for the banks to be ready in doing business electronically. The result on organizational framework suggests that banks e-readiness is not necessarily influenced by organizational competence. This finding is contrary to the findings of Chwelos et al (2001). Also, market e-readiness does not influence banks e-readiness. This finding is contrary to the findings of Molla and Licker (2005).

\section{Conclusion}

Based on the findings from the study, it can be concluded that e-readiness of Ghanaian banks are dependent on the technology readiness, government readiness and consumer readiness. The study recommends that future research can be conducted on the same banks after a while to determine their level of e-readiness. Also, different factors as moderators may be used in future research to assess the e-readiness of Ghanaian banks.

\section{References}

i. Adams, A. \& Lamptey, A., 2009. Customer perceived value in internet banking in Ghana.. Winneba: University of Education.

ii. Adesina, A. \& Ayo, C., 2010. An empirical Investigation of the Level of Users' acceptance of E-Banking in Nigeria. Journal of Internet Banking and Commerce, 15(1), p. 1-13.

iii. Alaaraj, H. \& Ibrahim, F. W., 2014. An Overview and Classification of E-Readiness Assessment Models. International Journal of Scientific and Research Publications, 4(12), pp. 1-5.

iv. Ali, H. \& Alrayes, A., 2014. An Empirical Investigation of the Effect of E-Readiness Factors on Adoption of EProcurement in Kingdom of Bahrain. International Journal of Business and Management, 9(12), pp. 220-229.

v. Al-Majali, M. \& Mat, N. K., 2011. Modeling the antecedents of internet banking service (IBSA) in Jordan : A Structural Equation Modeling ( SEM) approach. Journal of Internet Banking and Commerce, 16(1), p. 1-15.

vi. Anamuah-Mensah, E. \& Marfo, G., 2009. E-Business Adoption in the Banking Industry in Ghana. Lulea: Lulea University of Technology.

vii. Bank of Ghana, 2016. www.bog.gov.gh/ . [Online] Available at: http:// www bog.bov.gh/ supervision-aregulation/ register-of-licensed-insitutions/ rural-a-community banks[Accessed 20 February 2017].

viii. Boateng, R., Molla, A., Heeks, R. \& Hinson, R., 2011. Advancing E-commerce Beyond Readiness in a Developing Economy: Experiences of Ghanaian Firms. Journal of Electronic Commerce in Organizations, 9(1), pp. 1-16.

ix. Budhiraja, R. \& Sachdeva, S., 2002. E-Readiness Assessment (India). [Online] Available at: http:/ / www.mit.gov.in/ 11/2002[Accessed 5 February 2017].

x. Dada, D., 2006. E-Readiness for developing countries: Moving the focus from the environment to the users. Electronic Journal on Information Systems in Develping Countries, 27(6), pp. 1-14.

xi. Domeher, D., Frimpong, J. \& Appiah, T., 2014. Adoption of financial innovation in the Ghanaian banking industry. African Review of Economics and Finance, 6(2), p. 88-114.

xii. $\quad$ Gobat, J., 2012. What Is a Bank?. Finance \& Development, 49(1), pp. 38-39.

xiii. Kahn, M. A., 2015. E-Readiness in Developing Countries: "A Descriptive Case Study on Banking Sector of Pakistan". Information and Knowledge Management, 5(1), pp. 22-33.

xiv. $\quad$ Liébana-Cabanillas, F., Muñoz-Leiva, F. \& Rejón-Guardia, F., 2013. The determinants of satisfaction with e-banking. Industrial Management \& Data Systems, 113(5), p. 750-767.

xv. Maugis, V. et al., 2005. Global e-Readiness-for What? Readiness for e-Banking. Information Technology for Development, 11(4), pp. 313-342.

xvi. Nasri, W. \& Zarai, M., 2014. Empirical analysis of internet banking adoption in Tunisia. Asian Economic and Financial Review, 4(12), pp. 1812-1825.

xvii. $\quad$ Ntsiful, S., Acka, G. K. \& Odorh, O., 2010. Customers' Adoption Behaviour in Internet Banking: A Comparative Analysis of Ghana and Sweden. Karlskrona: Blekinge Institute of Technology.

xviii. Pikkarainen, T., Pikkarainen, K., Karjaluoto, H. \& Pahnila, S., 2004. Consumer acceptance of online banking: an extension of the technology acceptance model. Internet Research, 14(3), p. 224-235. 
xix. Salimon, M. G., Yusoff, R. Z. \& Abdullateef, A. O., 2014. The Mediating Effects of e-Satisfaction on the Relationship between e-Banking Adoption and its Determinants: A conceptual Framework. Journal of Management Information System and E-commerce, 1(1), pp. 95-105.

xx. Turban, E., Lee, J., King, D. \& Chung, H. M., 1999. Electronic Commerce: A Managerial Perspective. New Jersey: Prentice Hall.

xxi. World Bank, 2003. ICT Infrastructure and E-Readiness Assessments in the Republic of Belarus, Minsk: National Academy of Sciences of Belarus.

xxii. Zakaria, M. S. \& Janom, N., 2011. Developing and Validating Readiness Measures of Inter-organizational E-commerce on SMEs. Journal of Internet Banking and Commerce, 16(3), pp. 1-15. 